\title{
外来种入侵的生物学与生态学基础的若干问题
}

\author{
黄建辉 ${ }^{1}$ 韩兴国 ${ }^{1}$ 杨亲二 $^{2}$ 白永飞 ${ }^{1}$ \\ 1 (中国科学院植物研究所植被数量生态学重点实验室 北京 100093) \\ 2 (中国科学院植物研究所系统与进化植物学重点实验室 北京 100093)
}

摘要: 外来物种的入侵及其所造成的危害已越来越为人们所认识。一个外来物种入侵一个新的生境无疑要具备一 定的条件, 尽管目前对这种条件的研究还只是初步的。首先从其自身来说, 需要有足够的入侵性, 这可以认为是入 侵种的生物学基础, 可能表现为具有多倍性、一定的遗传变异、杂合性或表型可塑性, 以及不同的交配系统等; 其次 一个物种的入侵成功还取决于入侵生境的可入侵性, 这可以认为是入侵种的生态学基础, 而新的种间关系的形成, 尤其是入侵种与其他种类的互惠共生关系的建成是关键。本文主要介绍了有关入侵种的生物学和生态学基础中 的一些最新进展, 希望有助于我国学者对相关研究内容的开展以及对有害外来种入侵的防治。

关键词：入侵种，入侵生物学，入侵生态学

中图分类号:Q16 文献标识码 : A 文章编号 : 1005-0094(2003)03-0240-08

\section{Fundamentals of invasive species biology and ecology}

HUANG Jian-Hui ${ }^{1}$, HAN Xing-Guo ${ }^{1}$, YANG Qin-Er ${ }^{2}$, BAI Yong-Fei ${ }^{1}$

1 Laboratory of Quantitative Vegetation Ecology , Institute of Botany, Chinese Academy of Sciences , Beijing 100093

2 Laboratory of Systematic and Evolutionary Botany, Institute of Botany, Chinese Academy of Sciences , Beijing 100093

\begin{abstract}
The impact of invasive species on native species , communities and ecosystems has been widely recognized. There must be some prerequisites for an alien species to invade a new environment, although the research on this aspect is still in a preliminary stage. Firstly, an invasive species must be invasive enough in itself or has some biological distinction, such as quantitative and qualitative differences in the genome, or patterns of recombination. Secondly, to invade successfully, a new environment for an invasive species must be invasible, and this we may call the ecological basis of invasion. An invasive species may need to establish new interactions with other species, especially those mutualistic relations such as animal-related pollination, seed dispersal by animals, mycorrhizal fungi, and symbioses between plants and nitrogen-fixing bacteria. In this article, we review some advances in research of invasive biology and ecology in order to facilitate relevant research in China and prevent dispersal and expansion of some harmful invasive species.
\end{abstract}

Key words : invasive species, invasive biology , invasive ecology

\section{1 引言}

Babbitt (1998) 在为一本有关外来种入侵的专著 作序时，第一句话便是“美国正在受到 侵略'”，外 来种 (植物和动物) 正在陆地和水域不断地扩大它 们的自然分布区。尽管也有人认为所谓的外来种入 侵是一种正常的自然现象，今天的入侵种，可能就是
明天的自然种（Young ,1999) ,但入侵种对生态系统 功能所造成的影响已经为越来越多的人所认识 (Evans et al. ,2001 ; Mack et al. ,2001 ; Meekins \& McCarthy , 2001 ; Scott et al. )。许多外来种的入侵 都是在人类活动的直接或间接帮助下完成的 $(\mathrm{Vi}-$ 
tousek et al. 1996 ;Ruiz et al. 2000 ;Mack et al. , 2000 ; Ricciardi \& Maclsaac, 2000 ; Sakai et al. , 2001 ),同时也被认为是全球气候变化的结果之一 ( D'Antonio \& Vitousek,1992)。SCOPE (环境问题科 学委员会, the Scientific Committee on Problems of the Environment) 在 1986 年提出了生物入侵研究中 3 个 迫切需要解决的问题, 即: (1) 决定一个物种成为入 侵者的因素; (2) 决定一个生态系统易受到生物入 侵的立地特征; (3) 在解决上述问题的基础上如何 优化管理系统( Williams et al. ,1986)。

外来种的入侵向生态学家和进化生物学家提出 了一个令人困惑的问题:即为什么一些外来的有机 体从来没有机会适应那些局部的生境, 却能逐渐成 势,并取代本地种,而正常情况下, 这种替代通常需 要一个相当长的历史时期 (Sax \& Brown ,2000)。是 什么因素决定了一个物种成为入侵者, 以及什么样 的生境特征决定一个生态系统的可入侵性，这是入 侵生物学和入侵生态学首要回答的两个问题, 而寻 找入侵种的普遍特征则是当前生物学家和生态学家 最为迫切的需求。一个入侵种是否具有与众不同的 生物学或生态学特征,目前仍没有肯定的答案。因 为有足够多的例外表明没有一组特征能够很好地描 述入侵种( Binggeli ,1996)。但是偶然的繁殖以及开 放生境的出现有利于外来种的传播（Gray，1986），而 较多的观点认为，一个物种成为入侵种总是能找到 一些以前存在的物种所不具备的有利特征 (Thompson ,1991)。

到目前为止, 寻求入侵种的普遍特征主要可以 从两个方面入手:首先是生物学方面的,如形态学、 细胞学以及遗传学特征, 而目前引起人们兴趣的特 征则是入侵种是否存在某些基因,使这些物种具有 入侵性。这可能使我们很容易联想起过去曾经十分 时髦的所谓的 犯罪基因”;其次是生态学方面的。 入侵种要在一个新的生境中爆发, 总是需要具备一 定的生态学条件，如该生境中是否存在其共生种，帮 助其获得更多的营养, 是否存在一些物种能够帮助 其传粉或传播种子, 帮助其繁殖。本文主要评述外 来种入侵的影响因素,包括入侵种的生物学基础 (即入侵种的入侵性) 和外来种入侵的生态学基础 (即入侵生境的可入侵性)。希望这一评述有助于 我国学者对相关内容研究的开展以及对有害外来种 入侵的防治。

\section{2 外来种入侵的生物学基础}

入侵性植物物种的一个基本特征是它们的种群 具有快速增长的能力, 即使开始时它们的密度很低 (Crawley et al. 1996)。一个明显的现象是一个成 功的植物入侵者通常表现出如下特征, 即与其本地 分布的同种个体相比, 具有更强的生命力, 表现为具 有更高的高度、更高的生物量、更大的种子产量、更 长的寿命等。这被归结为具有潜在生命力的基因型 的建立, 但对这一现象的研究还十分有限 (Willis \& Blossey ,1999)。从天敌和疾病中解放出来也被认为 是入侵种扩散的一个原因, 这一现象被归结为物种 表型的可塑性。

在英国,有相当数量的植物种的分布区正在扩 大。对它们的特征的进一步研究表明，分布区扩大 的物种与没有扩大的物种之间并没有明显的区分 (Thompson et al. 1995)。但 Horvitz et al. (1998) 分 析了 50 多个分类群，它们所在的属内具有可入侵性 的物种。研究发现这些分类群在不同的地区中基本 都保留了入侵性及相关的功能特征。假如一个植物 物种有入侵的历史, 并进行无性繁殖, 则它成为入侵 种的可能性较高 (Kolar \& Lodge,2001) ,如 Fallopia japonica (Hollingsworth ,2000)。目前已经总结出一 些入侵物种的篮选系统，如 Reichard \& Hamilton (1997) 的北美系统 ,Pheloung et al. (1999) 的澳大利 亚系统以及 Tucker \& Richardson (1995) 的南非系 统。篮选方法逐渐从定性向定量的方向发展 (Kolar \& Lodge 2001)。但是，所有这些入侵种的鉴别方法 多数依赖于宏观的特征,显然还需要作进一步的修 改 (Mack 2000)。

那么入侵种是否具有一些普遍的遗传学特征 呢? 对这个问题的探讨可以追溯到 1964 年在 Asilomar 举行的有关外来种入侵的研讨会。该研讨会主 要讨论了如何进行大范围分类群的比较调查, 特别 是对一些同源种组内为什么有的物种是成功的入侵 者,而有的则不是的现象进行了深入调查。在种间 水平上,对外来定居者与源种群进行了遗传变异的 比较研究 (Gray ,1986)。从 20 世纪的 60 年代到 80 年代的一些研究结果表明,成功的入侵物种具有遗 传学上的特征,包括多倍性、遗传变异、杂合性或表 型可塑性及不同的交配系统等。

\section{1 基因组的定量差异}




\section{（1）多倍性}

有关多倍体植物比它们的二倍体祖先具有更大 的异地定居潜力的思想最早出现于 20 世纪 30 年代 (Gray, 1986)。此后,多倍性与定居能力有关的观点 被广泛接受。与二倍体植物相比,多倍体植物具有 更大的占据开放生境的能力, 这被认为是为什么组 成北美温带植物区系的大部分植物是多倍体植物的 主要原因。野外分布的研究也表明，由于多倍体植 物能够成功入侵和占据变化幅度更大的环境, 导致 多倍体植物常比它们的二倍体近缘种的分布更广 泛。

举例来说, 互花米草 Spartina alterniflora $(2 \mathrm{n}=$ $62)$ 通过运输进入英国, 与本地种 $S$. maritima $(2 \mathrm{n}=$ $60)$ 杂交,形成不育的杂交后代 $(2 n=62)$ 。该杂交 后代染色体加倍后形成可育的大米草 ( $S$. angelica) $(2 n=120 \sim 124)$ 。大米草很重要的一个特征是能 够汇集大量潮水带来的沉积物，一个 $\mathrm{C}_{4}$ 植物生长在 一个 $\mathrm{C}_{3}$ 的环境中 (低 $\mathrm{CO}_{2}$ 含量)，从而具有极强的 耐受力 (能经受 $6 \sim 9$ 小时潮水的浸没)。大米草与 其二倍体的祖先相比, 具有更强的生命力及选择的 有利条件，如遗传多样性方面的有利条件（继承了 两套基因组，产生了新的生理特征) 以及杂交组合 的优势。因此，既保留了原来的优势，又形成了新的 优势 (Thompson，1991)。

(2) 基因组的大小

有关真核细胞 DNA 含量的多变性是否有功能 和进化上的意义，已引起了广泛的思考。同时,基因 组的大小可能影响到多个领域的研究 (Bennett, 1998 )。例如, 有花植物单倍体核 DNA 的含量小至 $0.2 \mathrm{pg}\left(1 \mathrm{pg}=10^{-12} \mathrm{~g}\right)$, 大到 $127.4 \mathrm{pg}$, 其差异超过 600 倍 (Bennett et al. ,1982)。核 DNA 组成看起来 对独立于编码信息的表现型有作用，从而与细胞大 小、最小细胞周期、减数分裂持续时间和最小世代时 间有关。一个比较普遍的假设认为,基因组的大小 与不同气候条件下的选择有关 (Grime \& Mowforth， 1982 )。然而目前还没有足够的证据把基因组的大 小与定居和入侵能力完全联系起来。

(3) B 染色体

B 染色体在植物和动物种群中广泛出现。据调 查,在禾本科和菊科 (2 科中都有许多杂草种类) 中， 大约 1000 种植物就有 200 种具有 B 染色体。虽然 植物生长的特性、与环境的相关性以及明显的选择
优势都与 B 染色体的多态性有关, 但还没有普遍的 式样将此类多态性与物种的入侵性完全联系起来 ( Jones ,1985)。

\section{2 基因组的定性差异}

是否一些成功的外来定居者在遗传学上更加多 变? 相关地, 以基因多态性或者个体表型的可塑性 为特征的物种是否具有更宽的环境耐受范围? 这是 生物学家们所关心的问题。通过比较不同物种组合 的遗传变异, 如各种群多态位点的数量, 每个位点的 等位基因数量, 或者每个个体杂合位点的平均数量, 可以了解自然种群中等位酶的变异。不过, 有人也 发现在动物种类中，广泛分布的种比分布范围狭窄 的种和本地种更具变异性,生境普适种总是要比生 境专一种具有更高的多态性。而对于植物来说，由 于交配系统更加多样，倍性更高，人们不仅把注意力 集中在遗传变异的普遍水平, 而且还关注它们在种 内和种间的分布 (Loveless \& Hamrick,1984)。首 先，广布种要比本地种或局域种具有更大的等位基 因数量, 但在它们的种群间变异较小; 其次, 虽然演 替后期种比演替早期种和杂草的种群变异更大, 但 物种间的多样性在不同的演替阶段似乎差异很小。

有关等位酶的资料显示,最稳定和起最重要作 用的是交配系统。在入侵生物学的研究中, 对有关 种群遗传结构格局和它们受交配系统影响方式的比 较，引发了一个关键的问题:即从总体上来说，种内 基因多样性具有怎样的代表性? 哪些将在入侵种群 中表现出来? 换句话说,在个体特征水平上,那些基 因是否代表了被选择的定居能力?

此外，不论交配系统的作用如何，入侵过程本身 对定居者和源种群中变异的相对数量具有至关重要 的作用，如定植者数量多少 (种群瓶颈)、定植事件 发生的频率 (重复迁移) 以及入侵在多少距离以外 发生 (决定来自区域中心和外围种群的定植者是否 具有相同的能力)。在入侵过程及其相关作用上, 定居者和非定居者之间，或者定居者与源种群之间 基因变异水平的稳定差异可能很难找到，很显然目 前还不能将理想定居种在表型水平上显示出来的所 谓 普遍适应性” “更大的生理耐受” 以及“资源利 用的普适性” 等特征解释成基因型上的变异。

在论及植物定居能力时, 经常谈论的一个话题 是这种能力建立在遗传变异或表型可塑性基础上的 程度, 两者被认为是植物成功定居的两个途径。要 
分析这两个途径的有效性,在同一个种内分别是成 功定居和非成功定居的不同居群间，可以通过控制 引种实验进行详细的比较和分析。有证据表明,有 更多变异的居群是更成功的定居者, 从而具有更大 的入侵性。

\section{3 重组式样}

成功的定居也可能和单亲模式的繁殖有关，即 自体受精、单性生殖 (无配生殖) ,或克隆繁殖。这 一看似普遍的现象却成为生态学上的一个范式, 即 一年生杂草要么是自体受精, 要么是无配生殖; 或者 如果是杂交, 则趋向于以风媒传粉为主;多年生杂草 则可能是自花传粉的，或进行广泛的营养繁殖 :总之 是采用适当的基因型进行迅速的个体增加（Baker， 1974 )。

然而, 前述交配系统对植物居群遗传结构具有 深远的影响，自花授粉和近缘个体间的杂交增加了 组合配子之间的相关性, 减少了重组，维持了配子阶 段的不平衡 (Loveless \& Hamrick,1984)。远交则减 少组合配子间的相关性, 通过增加居群内有效的个 体数量, 减小了居群间的进一步分化。自交衰退是 一个普遍现象, 而有关自花授粉或无配生殖可以避 免异型杂合的现象目前还无法被证明。植物的交配 系统也是极其灵活的,新的重组基因型事实上也很 少出现。虽然交配系统在考虑植物定居能力时受到 了相当大的重视，但染色体和基因控制的重组不应 该被忽略。事实上,它们可能在杂交植物中保留有 益的重组基因时起到了促进的作用（Vila et al. , 2000 )。

\section{3 外来种入侵的生态学基础}

植物之间因为养分而存在强烈的竞争关系, 使 得外来种进入一个植物群落需要克服一定的不利因 素。当然, 不同的植物群落可能会有很大的不同。 相对稳定的群落, 如自然的森林和草地, 外来种的数 量相对较少; 而一些人为构建的群落，外来种数量则 相对较多。一个植物群落的可入侵性与植物平均覆 盖度有密切的关系, 那些富含外来种的植物群落还 与强烈的干扰、较低的土壤养分水平、土壤中高的有 毒物质含量以及非常小的土壤种子库有关。不过， 实际的研究结果有时可能与上述结论并不完全吻合 (Levine 2000 ;Stohlgren et al. 2001)。

外来种入侵一个竞争水平相对不高的生境时，
其成功的可能性相对较高。例如在一个生态系统的 营养层次中, 草食动物比肉食动物和腐食动物入侵 成功的可能性更大。对于植物而言，入侵一个盖度 越小的群落, 其成功的可能性越大; 而对于昆虫来 说，起决定作用的可能是它的内禀增长率。Crawley (1986) 曾提出了一个入侵物种通用的种群动态模 型，该模型在计算物种增长速率时，分别强调了以下 几个因素: (1) 清楚区分资源利用竞争与干扰竞争 的重要性; (2) 天敌的潜在重要性; (3) 互惠的作用; (4) 影响外来物种定植的各种避难所的重要性。不 过,他自己也承认对入侵物种种群动态过程的认识 还远远不够。

\section{1 入侵生态学}

由于生物入侵现象正在不断受到重视，而与生 物入侵相关问题的严重性也逐渐为人们所认识, 有 关生物入侵的生态学研究也逐渐形成一个新的生态 学分支学科, 即入侵生态学。它主要研究物种的入 侵性、生境的可入侵性以及入侵后的影响。“入侵 性” 主要研究什么样的特征使得一个物种能够入侵 一个新的生境“; 可入侵性”主要研究是什么决定了 一个群落或生境易受到一个新物种的建成和扩散 ; 入侵后的影响”主要考虑在一个现有物种和过程 的生境上增加一个物种会产生什么样的结果。

有关入侵、入侵性以及入侵种定义的多样化常 使人们产生混淆。所谓入侵, 应该是指以一种敌对 的方式进入。它包括两个步骤:首先要进入一个地 方, 其次是对那里的生物及生境有负作用。入侵种 (invasive species) 并不等于非本地种 (non-native species) ;而非本地种在条件合适时,可能转变成入 侵种; 但本地种也有可能成为入侵种, 称为本地入侵 种。对于入侵种的定义,生态学家与政府官员可能 有明显的不同。政府对入侵种的定义主要建立在它 们对经济、环境甚至人类健康影响的基础上,而生态 学家的定义则建立在它们在一个新的生境中扩散的 基础上。Daehler (2001) 认为，对于入侵种的定义不 应该考虑它们的影响。但相反的意见则认为, 生态 学家如果要对制止入侵种的扩散有所帮助, 就应该 尽可能不提出容易令人产生混淆的概念 (Davis \& Thompson 2001)。

\section{(1) 物种的入侵性}

尽管有了较多的研究，选择适合的特征以鉴别 一个植物的入侵趋势是十分困难的 (Reichard \& 
Hamilton，1997)。目前被认为与入侵性密切相关的 特征有:广的分布和快速的扩散能力。这两个特征 可以进一步引申为具入侵性的物种的生活史较短、 结果时期较长、种子数量较大、种子体积较小、种子 存活时间较长、易于被风和动物传播等。上述特征 可以说明一个物种可能比其他物种更具有入侵性， 但没有解释哪些特征会促进入侵性。有人提议用 表型的可塑性”,但并没有研究证明这种可塑性就 是与入侵性有关联。另外,一些研究也指出生活型 或功能群与可入侵性有关, 但没有哪一种生活型在 所有生境中都具有入侵性。有人提出了“不相似入 侵者”理论，但也没有很好的验证。要验证上述假 说, 需要对入侵种和非入侵性的非本地种的特征进 行大量的调查、分析和比较 (Alpert et al. ,2000)。 物种的其他一些特征如化学他感作用也可能帮助一 些入侵物种的扩散 (Ridenour \& Callaway 2001)。

\section{(2) 生境的可入侵性}

生境的可入侵性和物种的入侵性是一对作用事 物的两个方面。已经证明比较生境可入侵性的差异 要比甄别外来种入侵性特征容易。下列生境被认为 是容易被入侵的:即具有相对较少本地种的生境，干 旱 (但不一定是半干旱生境), 盐沼和高山, 沙地或 高低不平的土壤生境, 片断化生境, 河岸生境, 岛屿 生境。这些生境主要有如下的特征:地理和历史上 的隔绝，本地植物具较低的多样性（Dukes，2001）, 大的自然干扰和较多的人为活动，缺乏共同适应的 天敌(包括竞争者、捕食者、草食动物、寄生者和疾 病)。这些特征可以进一步引申为生境的进化历 史、群落结构、繁殖体方面的压力、干扰、逆境等。从 目前的工作来看，低的养分、水分和光照的可获得性 能够降低生境的可入侵性 (Huenneke et al. ,1990)， 但低的资源的可获得性有时也会有利于物种的入侵 (Alpert et al. 2000)。群落中物种的丰富度、功能 的多样性以及功能群的特性也都被认为与生境的可 入侵性有关 (Prieur-Richard et al. 2000)。

Davis et al. (2000) 提出了一个有关可入侵性的 普遍理论, 认为资源可获得性的波动是控制生境可 入侵性的关键因子:如资源供给经常处于一种波动 状态的生境要比具有稳定的资源供给的环境容易受 到入侵，当一个生境中的限制性资源突然升高或降 低时更易受到入侵, 受干扰、疾病或虫害侵袭后的生 境的可入侵性也将增加。资源供给增加后, 当本地
的植物能利用这些资源所间隔的时间延长时，可入 侵性增加; 群落引入牧食者后, 将使得生境更容易受 到入侵。然而，植物群落的物种多样性和可入侵性 之间没有必然的联系, 植物群落的平均生产力和可 入侵性之间也没有普遍的联系。Burke \& Grime (1996) 给出了另外的解释:一个本地群落对入侵的 敏感性与群落中可利用空间的可获得性有极大的关 系，而且当干扰和富营养化相配合时，入侵成功的可 能性最大。

\section{2 外来物种的入侵与共生}

一个物种能够成功入侵一个新的生境, 必须克 服许多的不利因素，例如它需要获得足够的养分完 成形态建成, 需要传粉者帮助它完成有性生殖过程, 而最重要的还是需要足够多的传播者帮助它完成扩 散 ( Simberloff \& von Hole ,1999)。因此,在新的生境 中入侵种能否获得足够的互惠或者共生关系, 对它 的成功繁殖和扩散具有至关重要的作用(图 1)。这 一类的种间关系主要有动物参与的授粉、动物对种 子的传播、菌根的形成、植物与固氮菌的共生等类 型, 而人为活动的影响将大大改变上述关系形成的 可能性。

外来植物十分需要共生和互惠的对象来克服新 的环境中存在的阻隔 (Christian , 2001)。在大多数情 况下，外来植物通常都很容易找到这些对象 (Bronstein 2001 Stachowicz，2001）。因此，可以假设:许多 生态系统之所以容易受外来植物入侵的一个最重要 的原因是互惠共生对象的容易获得。许多引入的植 物在新的生境中通常没有原生境中的专一传粉者, 但 在一般传粉者的帮助下也能迅速繁殖。具有肉果植 物 (通常是乔木或灌木) 中的许多种类在普通的当地 食果动物的帮助下能够成功入侵一个新的生境。丛 枝菌根在早期植物定居和帮助植物获得营养上起了 很大的作用。虽然植物和固氮菌之间的共生对外来 种入侵的作用目前还没有得到很好的重视，但许多臭 名昭著的杂草 (木) 是固氮植物或灌木。包含外来物 种的兼性 (非专一性) 作用关系在自然界是十分普遍 的, 这对非本地植物加速入侵自然群落是十分重要 的。外来种之间的兼性关系称为入侵复合体” 是广 泛存在的, 并且随着物种在全球范围的广泛运动和人 类对生态系统的干扰, 生态系统的可入侵性越来越 大。物种之间的互惠关系可以帮助我们预测外来物 种 (或者非本地物种) 的入侵性。 


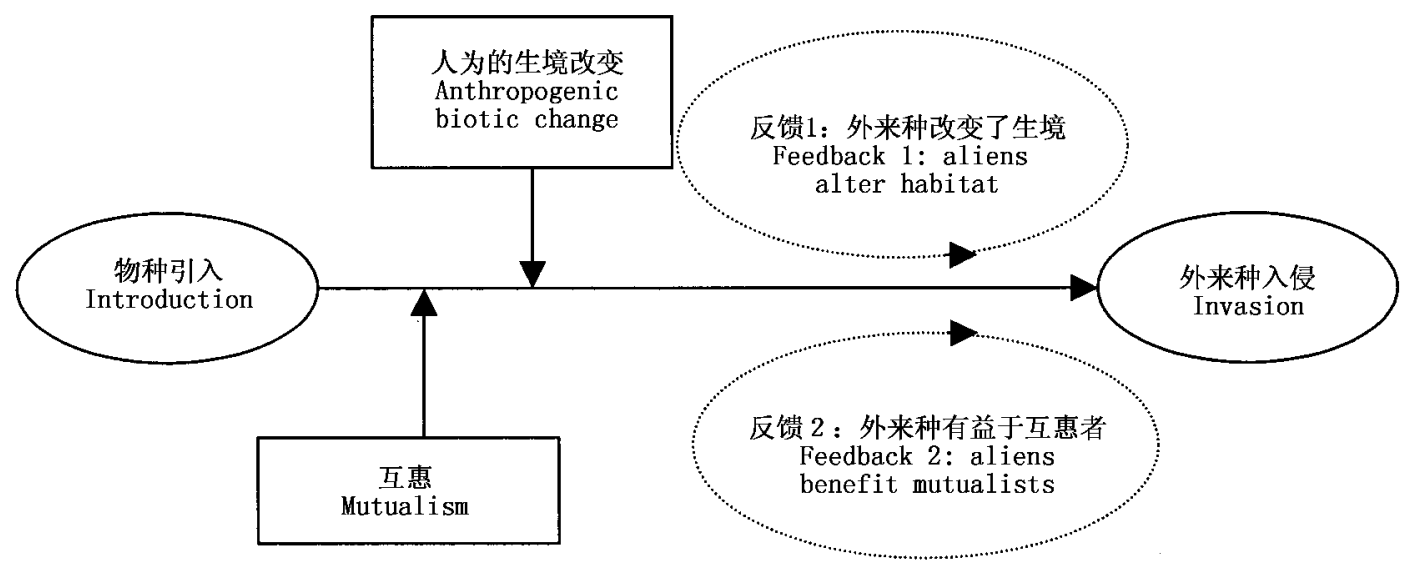

图 1 在共生体的帮助下，外来种入侵的一般模式 (Richardson et al. 2000)

Fig. 1 General model of invasion of alien plants facilitated by mutualisms

\section{4 结论}

外来物种的扩散及其所造成的危害已越来越为 世人所关注, 但我们对外来种的认识及研究却似乎 远远落后于外来种的扩散及其所造成危害的增长速 率。原因可能有两个方面:首先是外来种形成的复 杂性，一个物种成为入侵种有内在的原因，即可能有 一定的生物学基础，也有外在的原因，即外来种入侵 的生态学基础，如生境的可入侵性;其次是外来种形 成的滞后性，一个物种被引入一个新的生境后，有可 能潜伏几年、几十年甚至更长的时间。一个当前造 成巨大危害的入侵种在以前的群落只是一个不占优 势的伴生种，而也许现在没有危害的一个引入种、已 归化种或可能就是本地种，在将来某一个时刻会成 为一个入侵种。

目前对外来种的研究还只能是非常初步的和表 面的。目前的研究结果似乎表明,一个外来种有一 定的生物学基础, 如具有多倍性、一定的遗传变异、 杂合性或表型可塑性以及不同的交配系统等,但所 有的研究结果似乎还并不具有普遍性的意义。

一个物种的成功入侵还必须有一定的生态学基 础。因为,一个成功的入侵者必须要在一个新的生 境顺利完成其生长、繁殖和扩散过程, 而这很大程度 上不仅取决于一个物种的入侵性 (如生物学上或遗 传学上的特征), 而更重要的是被入侵生境的可入 侵性 (通常可以认为是生态学上的特征), 如新的种 间关系的形成,更重要的是互惠共生关系的建立。
但是, 成功阻隔一个入侵种进入一个新的生境的一 些生物学上的限制和生态学的阻隔在人为活动的影 响下变得微不足道, 即人类活动使得一些不可能的 入侵成为可能,使得一些本来需要几十年或更长时 间形成的入侵在短时间内完成，或者使一些潜伏着 的入侵突然爆发。对于外来物种的入侵, 经济的和 社会的因素常常与生物学的因素同样重要。因此, 预防入侵种的蔓延和爆发，人类必须首先注意自身 的行为。

虽然有关生物入侵的生态学研究可以追溯到十 年或二十年以前, 而对生物入侵的生物学研究则更 早, 并且已经取得了一些进展, 但显然还缺乏综合 性、概括性和预测性。下列内容值得进一步研究, 这 些研究对决策有着同样重要的意义: (1) 必须对入 侵种的扩散有一个更好的理解。例如对当前入侵的 区域评估可以通过时间系列图来显示入侵的过程和 途径, 并与气候变化图相结合，了解入侵的源、方向、 强度，甚至一些间接的因素。同时，我们也需要深入 了解一些迁移失败的物种的种群生物学, 因为这可 以帮助我们甄别能阻隔入侵的征兆; (2) 对入侵物 种扩散的实验研究也是十分必要的。到目前为止, 大多数资料主要来自观察。我们可以尝试对一些无 害扩散展开实验，从中得到一些规律性的结论。事 实上,对一些物种侵入世界各地的追踪研究已经为 我们提供了这方面的一些信息 (Novak \& Mack, $2001) ;$; (3) 对生物入侵造成的经济上的损失过去仅 限于小区域的个别物种，但全世界范围内反映生物 
入侵对经济影响的投资-效益分析则同样也是值得 的; (4) 对待物种互惠共生及生态学过程的机制的 进一步研究将有助于我们了解物种入侵的潜在趋 势; (5) 有关物种的侵入生物学研究，尽管过去曾尝 试寻找入侵物种的形态学、遗传学以及生态学特征, 但到目前为止几乎没有任何带有普遍性意义的结 果,因此需要通过采用分子生物学、基因组学,甚至 蛋白质组学的手段，对入侵物种展开遗传学和进化 生物学的研究, 特别是大范围比较入侵物种与其源 种群间显著差异的特征, 从而最终阻止世界植物和 动物区系的均匀化趋势。

\section{参考文献}

Alpert P., Bone E. and Holzapfel C. 2000. Invasiveness, invasibility and the role of environmental stress in the spread of non-native plants. Perspectives in Plant Ecology, Evolution and Systematics, 3: $52-66$.

Babbit B. 1998. Foreword. In: Devine R. (ed.), Alien Invasion: America's Battle with Non-native Animals and Plants. National Geography Society, Washington, D. C.

Bennett M. D. 1998. Plant genome values: how much do we know? Proceedings of the National Academy of Sciences, USA, 95: 2011 - 2016.

Bennett M. D., Smith J. B. and Heslop-Harrison J. S. 1982. Nuclear DNA amounts in angiosperms. Proceedings of the Royal Society of London B, 274: 227 - 274.

Baker H. G. 1974. The evolution of weeds. Annual Review of Ecology and Systematics, 5: $1-24$.

Binggeli P. 1996. A taxonomic, biogeographical and ecological overview of invasive woody plants. Journal of Vegetation Science, 7: $121-124$.

Bronstein J. L. 2001. The exploitation of mutualisms. Ecology Letters, 4: $277-287$.

Burke M. J. W. and Grime J. P. 1996. An experimental study of plant community in invasibility. Ecology, 77: $776-790$.

Crawley M. J. 1986. The population biology of invaders. Philosophical Transactions of the Royal Society of London B, 314: 711 - 731 .

Crawley N. J., Harvey P. H. and Purvis A. 1996. Comparative ecology of the native and alien floras of the British Isles. Philosophical Transactions of the Royal Society of London B, 351: $1251-1259$.

Christian C. E. 2001. Consequences of a biological invasion reveal the importance of mutualism for plant communities. Nature, 413: 635 - 639 .

D'Antonio C. M. and Vitousek P. M. 1992. Biological invasions by exotic grasses, the grass/fire cycle, and global change. Annual Review of Ecology and Systematics, 23: 63 - 87.

Daehler C. C. 2001. Two ways to be an invader, but one is more suitable for ecology. Bulletin of the Ecological Society of America, 82: $101-102$.

Davis M. A. and Thompson K. 2001. Invasion terminology: should ecologists define their terms differently than others? No, not if we want to be of any help! Bulletin of the Ecological Society of America, 82: 206.

Davis M. A., Grime J. P. and Thompson K. 2000. Fluctuating resources in plant communities: a general theory of invasibility. Journal of Ecology, 88: 528 - 534.

Dukes J. S. 2001. Biodiversity and invisibility in grassland microcosms. Oecologia, 126: 563 - 568 .

Evans R. D., Rimer R., Sperry L. and Belnap J. 2001. Exotic plant invasion alters nitrogen dynamics in an arid grassland. Ecological Applications, 11: 1301 - 1310.

Gray A. J. 1986. Do invading species have definable genetic characteristics? Philosophical Transactions of the Royal Society of London, B314: 655 - 674.

Grime J. P. and Mowforth M. A. 1982. Variation in genome size - an ecological interpretation. Nature, 299: 151 - 153.

Hollingsworth M. L. 2000. Evidence for massive clonal growth in the invasive weed Fallopia japonica (Japanese knotweed) . Botanical Journal of the Linnean Society, 133: 463 -472 .

Horvitz C., Pascarella J., McMann S., Freedman A. and Hofsetter R. H. 1998. Functional roles of invasive non-indigenous plants in hurricane-affected subtropical hardwood. $E c$ ological Applications, 8: 947 - 997.

Huenneke L. F., Hamburg S. P., Koide R., Mooney H. A. and Vitousek P. M. 1990. Effects of soil resources on plant invasion and community structure in Californian serpentine grassland. Ecology, 71: $478-491$.

Jones R. N. 1985. Are B chromosomes selfish? In: CavalierSmith T. (ed.), Evolution of Genome Size. John Wiley \& Sons, New York, $397-425$.

Kolar C. S. and Lodge D. M. 2001. Progress in invasion biology: predicting invaders. Trends in Ecology and Evolution, 16: $199-204$

Levine J. M. 2000. Species diversity and biological invasions: relating local process to community pattern. Science, 288: $852-854$.

Loveless M. D. and Hamrick J. L. 1984. Ecological determinants of genetic structure in plant populations. Annual Review of Ecology and Systematics, 15: 65 - 95.

Mack M. C., D'Antonio C. M. and Ley R. E. 2001. Alteration of ecosystem nitrogen dynamics by exotic plants: a case study of $\mathrm{C}_{4}$ grasses in Hawaii. Ecological Applications, 11: $1323-1335$.

Mack R. N. 2000. Assessing the extent, status, and dynamism of plant invasions: current and emerging approaches. In: Mooney H. A. and Hobbs R. J. (eds.), Invasive Species in A Changing World. Island Press, Washington D. C. 141 168.

Mack R. N., Simberloff D., Lonsdale W. M., Evans H., Clout M. and Bazzaz F. 2000. Biotic invasions: causes, epidemiology, global consequences and control. Issues in Ecolo$g y$, 5: $1-19$. 
Meekins J. F. and McCarthy B. C. 2001. Effects of environmental variation on the invasive success of a nonindigenous forest herb. Ecological Applications, 11: 1336 - 1348 .

Novak S. J. and Mack R. N. 2001. Tracing plant introduction and spread: genetic evidence from Bromus tectorum (cheatgrass). BioScience, 51: $114-122$.

Pheloung P. C., Williams P. A. and Halloy S. R. 1999. A weed risk assessment model for use as a biosecurity tool evaluating plant introductions. Journal of Environmental Management, 57: $239-251$.

Prieur-Richard A-H., Lavorel S., Grigulis K. and Dos Santos A. 2000. Plant community diversity and invasibility by exotics: invasion of Mediterranean old fields by Conyza bonariensis and Conyza canadensis. Ecology Letters, 3: 412 422.

Reichard S. H. and Hamilton C. W. 1997. Predicting invasions of woody plants introduced into North America. Conservation Biology, 11: $193-203$.

Ricciardi A. and Maclsaac H. J. 2000. Recent mass invasion of the North American Great Lakes by Ponto-Casoian species. Trends in Ecology and Evolution, 15: 62 - 65.

Richardson D. M., Allsopp N., D'Antonio C. M., Milton S. J. and Rejmanek M., 2000. Plant invasions - the role of mutualisms. Biological Reviews, 75: 65 - 93.

Ridenour W. M. and Callaway R. M. 2001. The relative importance of allelopathy in interference: the effects of an invasive weed on a native bunchgrass. Oecologia, 126: $444-$ 450.

Ruiz G. M., Fofonoff P. W., Carlton, J. T., Wonham M. J. and Hines A. H. 2000. Invasion of coastal marine communities in North America: apparent patterns, processes, and biases. Annual Review of Ecology and Systematics, 31: 481 -531 .

Sakai A. K., Allendorf F. W., Holt J. S., Lodge D. M., Molofsky J., With K. A., Baughman S., Cabin R. J., Cohen J. E., Ellstrand N. C., McCauley D. E., O `Neil P., Parker I. M., Thompson J. N. and Weller S. G. 2001. The population biology of invasive species. Annual Review of Ecology and Systematics, 32: 305 - 332.

Sax D. F. and Brown J. H. 2000. The paradox of invasion. Global Ecology and Biogeography, 9: 363 - 371 .
Scott N. A., Saggar S. and McIntosh P. D. 2001. Biogeochemical impact of Hieracium invasion in New Zealand's grazed tussock grasslands: sustainability implications. Ecological Applications, 11: $1311-1322$.

Simberloff D. and von Hole B. 1999. Positive interactions of nonindigenous species: invasional meltdown? Biological Invasions, 1: $21-32$.

Stachowicz J. J. 2001. Mutualism, facilitation, and the structure of ecological communities. BioScience, 51: $235-246$.

Stohlgren T. J., Otsuki Y., Villa C. A., Lee M. and Belnap J. 2001. Patterns of plant invasions: a case example in native species. Biological Invasions, 3: $37-50$.

Thompson J. D. 1991. The biology of an invasive plant (Spartina angelica). BioScience, 41: $393-401$.

Thompson K., Hodgson J. G. and Rich T. C. G. 1995. Native and alien invasive plants: more of the same? Ecography, 18: $390-402$.

Tucker K. C. and Richardson D. M. 1995. An expert system for screening potentially invasive alien plants in South African fynbos. Journal of Environmental Management, 44: 309 338.

Vila M., Weber E. and D'Antonio C. M. 2000. Conservation implications of invasion by plant hybridization. Biological Invasions, 2: $207-217$.

Vitousek P. M., D'Antonio C. M., Loope L. L. and Westbrooks R. 1996. Biological invasions as global environmental change. American Scientist, 84: $468-478$.

Williams M. H., Sir Hans Kornberg F. R. S., Holdgate M. W., Gray A. J. and Conway G. R. 1986. The British contribution to the SCOPE Programme on the ecology of biological invasions. Philosophical Transactions of the Royal Society of London B, 314: 503 - 504.

Willis A. J. and Blossey B. 1999. Benign environments do not explain the increased vigour of non-indigenous plants: a cross-continental transplant experiment. Biocontrol Science and Technology, 9: 567 - 577.

Young A. M. 1999. Invaders today, natives tomorrow? Science, 286: 901 .

(责任编辑：孙大川) 